УДК 821.161.2-31Андр7Сьомга.09

DOI https://doi.org/10.26661/2414-9594-2021-1-31

\title{
МЕХАНІЗМИ НАРАТИВІЗАЦІЇ СЕМІОТИЧНИХ КОДІВ ЖИТЛА В РОМАНІ СОФІЇ АНДРУХОВИЧ «СЬОМГА»
}

\author{
Гребенюк Т. В. \\ доктор філологічних наук, професор, \\ професор кафедри культурологї та українознавства \\ Запорізький державний медичний університет \\ пр. Маяковського, 24, Запоріжжя, Украӥна, \\ orcid.org/0000-0003-1910-5411 \\ s_gtv@ukr.net
}

Ключові слова: наратив, семіотичний код, семіозис, тілесність, наративізація.
У статті досліджуються механізми наративізації семіотичних кодів житла в романі Софії Андрухович «Сьомга». Образи помешкань нараторкипротагоністки розглядаються в контексті редуплікації в них сутності центрального наративу роману - історії втручання чужого в індивідуальноособистісну, зокрема тілесну, сферу протагоністки. Методологія аналізу поєднує семіотичні й наратологічні підходи до тексту та грунтується на працях А.Дж. Греймаса, С. Сневарра, А. Арбантес, Н. Городнюк, Р. Савчук, $\Phi$. Штейнбука та інших науковців. Паралель між тілом і помешканням оцінюється як засаднича для індивідуального стилю С. Андрухович.

Кожна новела у складі роману «Сьомга» містить образи помешкань, які семіотизують аспекти особистісного становлення нараторки й пов'язані 3 формуванням і рефлексією iii тілесності в аспекті пошуку меж між собою та іншим. Описані будівлі впливають на сприймання оповіді читачем, втілюють семіотичні коди, значущі для сприйняття центрального наративу, реалізуючи в такий спосіб сугестивну функцію художньої літератури.

У новелі «Володар світла, повелитель води» таку функцію виконує локус усамітнення - квартира протагоністки в «хрущовці», за якою стежить сантехнік Кухарук. У новелі «Кров» центральний наратив редуплікується через семіотику обставленої дзеркалами спальні і хисткої «хатки» біля моря. У новелі «Райський сад і прилеглі території» формування дитячої психіки протагоністки семіотизується через локуси «дурдому», «стройки» та «дитячого садку» як місць перманентного приниження. У новелі «Морські розбійники та діва Марія» квартира протагоністки асоціюється 3 iii тілом, а пограбування житла виступає семіотичним аналогом згвалтування оповідачки. У новелі «Диявол ховається в рисі» описані помешкання протагоністки є тимчасовими подібно до необов'язкових стосунків із неприємним їй хлопцем. Остання новела «Я хочу пізнати твій внутрішній світ» розглядається як абсурдистське втілення насильницької експансії чужого в життя протагоністки, де розтин тіла дівчини Кухаруком виступає метафорою, що поглиблює ідею згубності втручання у світ іншого. 


\title{
MECHANISMS OF NARRATIVIZATION OF SEMIOTIC CODES OF HABITATION IN THE NOVEL "THE SALMON" BY SOFIA ANDRUKHOVYCH
}

\author{
Grebeniuk T. V. \\ Doctor of Philology, Professor, \\ Professor at the Department of Ukrainian and Cultural Studies \\ Zaporizhzhia State Medical University \\ Mayakovsky avenue, 26, Zaporizhzhya, Ukraine \\ orcid.org/0000-0003-1910-5411 \\ s_gtv@ukr.net
}

Key words: narrative, semiotic code, semiosis, corporeality, marrativization.
In the article there are investigated mechanisms of semiotic codes narrativization of habitation in the novel "The Salmon" by Sophia Andrukhovych. Images of narrator-protagonist's habitations are considered in the context of reduplication in them the central novel narrative - the story of stranger's invasion of privacy, in particular, of the corporeal sphere. The research methodology combines semiotic and narratological approaches to the fiction text and is based upon the studies by A.J. Greimas, A. Abrantes, S. Snævarr, N.A. Horodniuk, R.I. Savchuk, F. Shteinbuk and others. Parallel between the body and the habitation is assessed as the pivotal in the Sophia Andrukhovych individual style.

Each novel as part of the novel "The Salmon" contains images of habitations that semiotize aspects of the narrator's personality formation and are connected with forming and reflection of her corporeality sphere in the aspect of search of the borders between the self and the other. The described dwellings influence reader reception of the narrative, represent the semiotic codes what are significant for comprehension of the central narrative, and perform the suggestive function of fiction literature in this way.

The analyzed novel consists of six short stories. In the short story "The Lord of Light, the Sovereign of the Water", the suggestive function is performed due to creation of the privacy locus - the protagonist's flat in "hrushchovka" watched by the plumber Kuharuck. In the short story "Blood" the central narrative is reduplicated through semiotics of the bedroom furnished by mirrors and the subtle house on the seashore. In the short story "The Garden of Eden and the Surrounding areas", formation of the protagonist's child mind is semiotized through the locuses of the "madhouse", "construction place", and "kindergarten" as places of the permanent humiliation. In the short story "The Sea Pirates, and Virgin Mary", the protagonist's flat is associated with her body, and the burglary of the apartment is seen as a semiotic analog of the rape of the narrator. In the short story "The Devil is Hidden in Rice" all described protagonist's habitations are temporary, like are temporary and non-binding her relationship with the guy who is unpleasant to her. The last short story "I Want to Learn your Internal World" is considered as an absurdist embodiment of the notion of stranger's violation of the protagonist's life. The dissection of the girl's body by Kuharuck is viewed as a metaphor deepening the idea of the stranger invasion of one's privacy balefulness.
Вступ. Вихід друком роману «Амадока» Софіï Андрухович, який став помітною подією в літературному житті України 2020 року, відчутно актуалізував увагу до попереднього доробку авторки, зокрема до іiі першого роману «Сьомга» (2007 рік). Погляд на твори письменниці як на певний цілісний семіотичний континуум $є$ сьогодні надзвичайно актуальним і доцільним, адже він дає змогу побачити стале й змінне у семіосфері великої прози авторки, виокремити певні повторювані семіотичні й наративні патерни та розглянути їх трансформацію від твору до твору. Тим більше, що творчість Софії Андрухович $€$ зразком письма, яке не містить довільних, випадкових елементів, натомість демонструє узгодженість процесів смислоутворення на різних рівнях 
поетики. Зокрема, на особливу увагу заслуговує співвідношення рівнів нарації (зокрема, творення особистісних історій протагоністів) і семіотизації дескриптивних елементів тексту. Можна сказати, що твори письменниці містять безліч образів, які за фрактальним принципом відбивають і редуплікують сутність центрального наративу, реалізуючи сугестивну функцію художнього письма. Так, надзвичайно важливими для смислоутворення в романах С. Андрухович $\epsilon$ описи помешкань протагоністів. Дескриптивні за своєю природою, вони виступають тлом центральної історії, а у своїх семіотичних характеристиках дублюють її зміст. Крім того, вони вплітаються в складну наративну структуру творів, формуючи загальний наративно-семіотичний контекст для засвоєння читачем головної історії (або головних історій).

Вважаємо, що для прози письменниці характерний специфічний підхід до локусів будівлі, помешкання, який пов'язує воєдино семіотику житла й тіла, наративізує закладені в ній семіотичні коди. Дуже яскраво оприявнено в образах житла зв'язок між семіотичним і наративним рівнями поетики твору як художнього цілого вже в першому романі письменниці «Сьомга». У наступних романах «Фелікс Австрія» і «Амадока» відбувається подальший розвиток прийомів, реалізованих у цьому романі ${ }^{1}$. Отже, для розуміння природи наративізації семіотичних кодів житла, помешкання у прозі письменниці важливо розглянути іiї принципи в поетиці роману «Сьомга».

Отже, метою статті $\epsilon$ аналіз механізмів наративізації семіотичних кодів житла й, зокрема, помешкань протагоністки в романі Софії Андрухович «Сьомга» в контексті редуплікації в них сутності центрального наративу роману.

Зважаючи на багатошаровість і полінаративність художньої тканини названого роману, уточнимо, що матиметься на увазі під його центральним наративом. Попри розмаїтість персонажної сфери та хронотопів новел у структурі роману, таким узагальнюючим наративом вважатимемо історію втручання чужого в індивідуально-особистісну, зокрема тілесну, сферу нараторки-протагоністки, найгострішим виявом якого на зовнішньо-подієвому рівні стало пограбування квартири й згвалтування дівчини.

Природа поставленої мети зумовлює методологію аналізу, в якій має бути поєднано семіотичні й наратологічні підходи до тексту. Попри розмаїття досліджень, присвячених семіотиці будівель

\footnotetext{
1 Зокрема, образ химерного будинку в романі письменниці «Фелікс Австрія» детально проаналізовано в контексті поетики екфразису в статті ««Магічний трюк, який несила розгадати»: архітектурний екфразис у романі Софії Андрухович «Фелікс Австрія№»» [11].
}

(помешкання) $)^{2}$, в контексті когнітивних механізмів функціонування семіотичного й наративного рівнів твору це питання розглядається нечасто. Серед засадничих спроб поєднання семіотичного й наратологічного підходів до художнього твору, безумовно, є ідеї Альгірдаса Дж. Греймаса, який стверджував, що значення є осягненим тільки тоді, коли воно наративізоване. Відповідно до цього, науковець виокремлював два рівні аналізу й репрезентації значення, а саме поверхневий $\mathrm{i}$ глибинний, на якому закладається основа наратованого ще до моменту його зовнішнього вираження. Семіотика А.Дж. Греймаса невіддільна від вивчення наративу як динамічного феномена. У iï межах учений розглядає послідовні фази, такі як семіотика дії, когнітивна семіотика й модальна семіотика, у межах якої дієва й когнітивна активність суб'єктів модифікується пристрастями, переконаннями й знанням [2].

Виклад основного матеріалу. На основі вчення А.Дж. Греймаса постала ціла галузь студій тексту й дискурсу на межі семіотики й наратології, в українській гуманітаристиці представлена, зокрема, працями Анатолія Загнітка (який номінував цю галузь наративною семіотикою [13]), когнітивними студіями Ольги Воробйової [3], дослідженнями Руслани Савчук [15]. Цікаву оптику бачення художніх об'єктів спостерігаємо в семіотико-наративних студіях Р. Савчук, яка сполучає ідеї семіотики й наратології із застосуванням інтердисциплінарної теорії можливих світів [15]. Названі студії реалізовано переважно в річищі мовознавства. Літературознавчі дослідження на межі семіотики й наратології часто являють собою погляд на твір через призму метафори. Наприклад, семіотико-наратологічний підхід до тексту Лоуренса О’Тула базується на трансформації дихотомічної моделі (бінарні опозиції структурної семіотики К. Леві-Стросса, В. Топорова, погляди Ю. Лотмана, Р. Барта) в багатовимірну [4]. Причому надзвичайної ваги науковець надає саме просторовим відношенням: «Одна семіотична система, просторові відношення, розглядається як така собі метафора для інших семіотичних систем тексту» [4, с. 136]. На визначальності просторової метафорики в художньому наративі наголошують також Стефан Сневарр [5] і Ана Маргаріда Арбантес, яка узагальнює місце просторових образів у художньому наративі: «Сдиним просторовим ключовим концептом під час репрезентації реальності є концепт світу. Він не тільки інформує про загальні обриси нашого контекстуального досвіду, але й виступає концептуальним засобом сенсотворення можливих, гіпо-

\footnotetext{
2 Зокрема, семіотичній інтерпретації дому, житла, помешкання, присвячено численні статті у ч. 13 наукового збірника «Сучасні літературознавчі студії» (2016 рік).
} 
тетичних реальностей, які ми зустрічаємо в літературному наративі» [1, с. 25-26].

Безумовно, в романах С. Андрухович просторові параметри подій наснажені смислами, визначальними для творення психології центральних образів. Сама письменниця, окреслюючи інтенційність текстотворення «Сьомги», акцентує орієнтованість оповіді на «місце», яке співвідноситься 3 певним періодом життя: «це своєрідний розтин певного періоду людського життя, така собі екскурсія місиями бойової слави» (курсив мій. - Т. Г.) [16].

Зазначимо також, що дім як просторовий, певною мірою речовий образ у прозі С. Андрухович виконує світомоделювальну функцію, яку Наталія Городнюк характеризує як «функцію структурування у семіосфері культури, уособлюючи головні культурні опозиції: «своє/чуже», «жіноче/чоловіче», «сакральне/профанне», «праве/ліве» тощо» $[10$, c. 58]. Серед найактуальніших для семіосфери С. Андрухович опозицій надзвичайної ваги набуває протиставлення «своє/чуже». У літературознавчому дискурсі творів письменниці воно також актуалізується як опозиція «Я/Інший». Зокрема, проблемі становлення ідентичності людини через опис приватного досвіду тіла і протиставлення суб'єктного «Я» образу «іншого» в романі «Сьомга» присвячено статтю Мирослави Крупки [14].

Софія Андрухович співвідносить житло людини зії внутрішнім світом у його можливій непривабливості, герметичній закритості до чужого втручання: «Ми замкнуті у своїх тісних черепах, як у маленьких білих кімнатах - кожному по одній, і навіть якби не хотіли, не могли б показати іншому своїх плутаних i вертлявих думок. Ми навіть не здогадуємось, що там діється, в інших кімнатах. Вдаючи близькість 3 кимось іншим, ми спокійні, бо знаємо, що цей інший ніколи не побачить товстих шарів пилюки по кутах $<\ldots>$, вивернутої просто на підлогу брудної білизни» [6, с. 67].

Загалом паралель між тілом і помешканням $\epsilon$ засадничою і для малої прози письменниці. Так, Олена Галета вбачає в проєкції зовнішнього простору помешкання на простір тілесності знакову сутність оповідання Софії Андрухович «Княгиня». Вторгнення Княгині до помешкання оповідачки оцінюється дослідницею як вираження тілесної агресії [8, с. 246-247]. У такий спосіб, через проєктування внутрішніх процесів назовні, у творах С. Андрухович відбувається одночасна семіотизація й наративізація психіки індивіда, зокрема почуттів і пристрастей. У своїй праці «Семіотика пристрастей» А.Дж. Греймас стверджує, що «саме власне тіло <..> забезпечує доступ до світу смислу взагалі. Це тіло, яке відчуває, сприймає, реагує, - тіло, яке мобілізує всі роз'єднані ролі суб'єкта в одному стисканні, здри- ганні, стрибку, переміщенні. Тіло як перешкода й зупинка, що призводить до соматизації суб'єкта, хворобливої або щасливої. Тіло як місце переходу й патемізації, що керує способами існування» [12, с. 328].

У кожній новелі роману «Сьомга» образ будівлі, помешкання вияскравлює, семіотизує певний аспект розвитку особистості протагоністки ${ }^{3}$, зокрема, пов'язаний зі становленням власної тілесності в аспекті пошуку іiі меж. Навіть якщо будівля не має прямого відношення до біографії нараторки (як, наприклад, «стройка», «дурдом»), вона впливає на сприймання оповіді, втілюючи певні семіотичні коди, значущі для сприйняття центрального наративу. Наприклад, у новелі «Володар світла, повелитель води» таку функцію виконує квартира в «хрущовці» (місце усамітнення й самовираження через секс, йогу, читання тощо), де мешкають протагоністка та їі хлопець Міша й куди постійно намагається заглядати через вікно (тобто втручатися в приватний простір дівчини проти їі волі) сантехнік Кухарук. У новелі «Кров» центральний наратив редуплікується через семіотику спальні, обставленої дзеркалами, у якій ховає від світу свою надмірну сексуальність родичка протагоністки, а також через образ хисткої «хатки» зі щілинами в підлозі, де нараторка та іiі тітка мешкали під час виїзду на море. У новелі «Райський сад і прилеглі території» світ часів дитинства протагоністки, формування ii психіки семіотизується через дискомфортні й токсичні локуси «дурдома», «стройки» та «дитячого садка», у яких суб'єкт зазнає принижень. В останньому 3 названих локусів принижень у дитинстві зазнає сама протагоністка. Зазначимо, що семіотика будівель у цій новелі надзвичайно важлива для розуміння формування тілесності нараторки, адже саме дитинство є періодом закладання основ тілесної і - ширше - індивідуальної ідентичності особистості, коли, за словами Ю. Ганошенка «вибудовується концепція межі (відмінності) власного внутрішнього «Я» і його конфронтація 3 «Іншими»» [9, с. 15]. Постійне насильницьке втручання у сферу персональної тілесності різних людей (здійснюване вихователькою, персоналом «дурдома» або реалізоване у сцені згвалтування біля «стройки», свідком якої мимоволі стала нараторка) задає параметри майбутньої ущербності, віктимності як норми поведінки для оповідачки.

У новелі «Морські розбійники та діва Марія» проводиться паралель між квартирою протаго-

3 Тут бачимо пов'язаний із образом будівлі сугестивний ефект, який Олена Вещикова спостерегла в прозовому циклі Галини Пагутяк «Особливі будинки», коли образи окремих будинків, як елементи мозаїки, формують цілісну картину художньої реальності творів письменниці в іiі глибинних екзистенційних вимірах [7]. 
ністки, полишеною на неї батьками, та ï тілом. Маємо ситуацію оприявнення внутрішнього дискомфорту, неоформленості життя дівчини в зовнішніх деталях, таких як недопалки, що переповнюють попільничку, безлад у кухні. Свідченням наявності внутрішнього стрижня, духовного осередку тілесності нараторки є iï зосередження на іконі Діви Марії з Ісусом, втрата якої внаслідок пограбування осмислюється нею як найболючіша.

Після пограбування квартири «друзями», які скористалися наївністю протагоністки, й зГвалтування ㄲi випадковим знайомим той комплекс почуттів i емоцій, який переживають жертви подібних злочинів, наративізується не прямо, а через ставлення дівчини до власного спаплюженого житла (тіло = житло): «Тепер, дивлячись на понівечений, розпачливо роззявлений, беззахисний у своїй покаліченості дім - місце, де раніше можна було відчувати себе захищено і затишно, $<\ldots>$ - я пригадувала, як ще в таксі передчувала тепло постелі і ніжну темряву знайомих кімнат. Тепер усе це було неможливим. Я навіть не могла уявити, що зможу коли-небудь перебувати тут, не відчуваючи страху, огиди, сорому, не думаючи про квапливі загребущі руки, котрі мацали мене зсередини» [6, с. 241-242].

У новелі «Диявол ховається в рисі» описані помешкання протагоністки є тимчасовими, прохідними (чужий дім за кордоном, орендована на час іспитів квартира тощо). Так само транзитними, прохідними й випадковими для оповідачки $є$ стосунки 3 потворним і неприємним закоханим у неї хлопцем, якого під час онлайн-спілкування вона демонізує, й очікує від нього проявів якоїсь інфернальної сексуальності. Звертає на себе увагу мазохістичність описаних стосунків дівчини 3 тим, хто в реальному спілкуванні оффлайн не подобається, нехтування своєю тілесністю й волею. У цій новелі в різноманітних модифікаціях на кількох семіотичних рівнях реалізується феномен моструозності. По-перше, залицяльник протагоністки є надзвичайно потворним і огидним: у нього «крихітні, розкосі, близько посаджені» очі, «безформні брови», «ледь розплюснутий м'ясистий ніс», «понівечена слідами від віспи шкіра», від нього постійно смердить тощо [6, с. 295]. По-друге, під час взаємодії з хлопцем оповідачка теж постійно отримує якісь пошкодження власної зовнішності (хоча на момент першої зустрічі з ним вона завважує власну вроду): руки, пошкрябані гіллям, спина, жахливо покусана мурахами тощо. По-третє, занедбаність, занехаяність тимчасового житла дівчини і взагалі локацій, де пара зустрічається, також має ознаки пошкоджень (обідрана фарба), недосконалості, занедбаності.

Протагоністка (очевидно, після досвіду згвалтування й зради друзів) ніби почувається внутріш- ньо потворною, гідною тільки найгірших і найпотворніших проявів життя: «йому справді краще було б поводитися зі мною саме так - недбало i грубо, показати байдужість і зверхність, і якось образити» $[6, \text { с. } 298]^{4}$.

Фелікс Штейнбук, аналізуючи постмодерністську прозу, розглядає монструозність як феноменологічний текстогенний корелят, що уможливлює поєднання «примітивної» тілесності та високих духовних досягнень у культурі загалом і у сучасній літературі зокрема [18, с. 33]. Вважаючи роман С. Андрухович «Сьомга» текстом, створеним на межі постмодернізму й метамодернізму, зазначимо, що в семіозисі твору ця реалізація монструозного переломлюється досить іронічно, адже протагоністка погоджується на занурення в гіпертрофовану потворність, дисфункційність, девіантність (гомосексуальні стосунки братів) не задля духовного зростання (жертва заради щастя хлопця) або падіння (пошуки диявола, тобто тілесної насолоди), а через власну низьку самооцінку та імпліковане життєвим досвідом віктимне відторгнення власних потреб. Ця відмова від адекватної сексуальної самореалізації корелює 3 наскрізністю образів чужих помешкань, у яких вимушено проживає оповідачка, не відчуваючи їх власним простором.

Абсурдистським апофеозом щодо розгортання насильницької експансії чужого в життя протагоністки є остання новела «Я хочу пізнати твій внутрішній світ», у якій сантехнік Кухарук знаходить-таки оповідачку після тривалої розлуки, вламується у іï нове житло й, розітнувши тіло дівчини, намагається «пізнати внутрішній світ» протагоністки. Це своєрідна метафора, яка поглиблює ідею згубності, фатальності втручання у світ іншого. Фрактальна образна редуплікація центрального наративу реалізується і в цій новелі, але вже виключно на абсурдистсько-іронічний манер: осягнення іншої свідомості звужується до осягнення чужої тілесності (тобто конкретних тканин, судин, м'язів, сухожиль тощо), яка семіотично оприявнюється через образ ванної кімнати, де сантехнік Кухарук почувається максимально комфортно й відчуває містичну залюбленість у «райський сад загнивання і прілості» в ній [6, с. 330].

Висновки. Можемо сказати, що в усіх новелах, які входять до складу роману Софії Андрухович

\footnotetext{
${ }^{4}$ Цікаво, що надалі, в романі «Амадока», Софія Андрухович повертається до семіотики потворного, але осмислює іiі в дещо іншому ключі: монструозність там утілено як у символі сучасного українського суспільства - образі Віктора-Богдана, по шматках зібраного хірургами й позбавленого власних спогадів, так і в образі помешкання пластичного хірурга професора Криводяка, де коридор обвішано фотографіями його спотворених пацієнтів, а житло вщент забите непотрібними речами. Монструозність другого типу корелює 3 підсвідомою травматичною рецепцією Криводяком подій Голокосту й Другої світової війни, у яких була морально скалічена його мати.
} 
«Сьомга», відбувається семіотична редуплікація центрального наративу роману - вторгнення чужої людини у сферу тілесності й духовного світу нараторки-протагоністки. Таке втручання в романі наративізується за принципом «скриньки в скриньці»: згубна небажана інвазія в психіку чужої людини уособлюється втручанням у їі тілес- ність, яка втілюється в тексті подією вторгнення в чуже помешкання. У контексті зроблених узагальнень надзвичайно перспективним видається подальше дослідження оприявнення семіотичних кодів, пов'язаних із локусом житла, в центральних наративах наступних романів письменниці «Фелікс Австрія» і «Амадока».

\section{ЛIТЕРАТУРА}

1. Abrantes A. From Space to Mental Space: A Cognitive Perspective into Narrative and the Architecture of the Human Mind. Diffractions. 2021. № 3. P. 10-28.

2. Greimas A.J. On Meaning: Selected Writings in Semiotic Theory / ed. and trans. P. Perron, F. Collins. Minneapolis : University of Minnesota Press, 1987. 239 p.

3. Language - Literature - the Arts: A Cognitive-Semiotic Interface / eds. E. Chrzanowska-Kluczewska, O. Vorobyova. Frankfurt-am-Maine : Peter Lang, 2017. 326 p.

4. O'Toole Lawrence M. Dimensions of Semiotic Space in Narrative. Poetics Today. 1980. Vol. 1. No. 4. Narratology II : The Fictional Text and the Reader. P. 135-149.

5. Snævarr S. Metaphors, Narratives, Emotions. Leiden, The Netherlands. 2010. 398 p.

6. Андрухович С. Сьомга : роман. Київ : Нора-Друк, 2014. 352 с.

7. Вещикова О. «Особливі» будинки у прозі Галини Пагутяк. Сучасні літературознавчі студії. Феномен дому в літературознавчій перспективі : збірник наукових праць / гол. ред. Н. Висоцька. Вип. 13. Київ : Вид. центр КНЛУ, 2016. С. 92-103.

8. Галета О. Незнайоме тіло сучасної української прози: жіноча література від Василя Габора. Парадигма. 2011. Вип. 6. С. 234-266.

9. Ганошенко Ю. Замулене межиріччя: межа як конструент ідентичності в романі «Месопотамія» Сергія Жадана. Наукові праиі. Чорноморського державного університету імені Петра Могили комплексу «Києво-Могилянська академія». Серія: Філологія. Літературознавство. 2017. Т. 301. № 289. С. 14-18.

10. Городнюк H. Res incognita: семіотика речі у східнослов’янському модерністському романі першої половини XX століття : монографія. Дніпро : Свідлер А., 2017. 560 с.

11. Гребенюк Т. «Магічний трюк, який несила розгадати»: архітектурний екфразис у романі Софії Андрухович «Фелікс Австрія». Сучасні літературознавчі студіі. Феномен дому в літературознавчій перспективі : збірник наукових праць / гол. ред. Н. Висоцька. Вип. 13. Київ : Вид. центр КНЛУ, 2016. С. $175-187$.

12. Греймас А.Ж., Фонтаний Ж. Семиотика страстей. От состояния вещей к состоянию души / пер. с фр. Москва : Издательство ЛКИ, 2007. 336 с.

13. Загнітко А. Лекція «Методи аналізу дискурсу і тексту: наративна семіотика (структурна семантика)». URL: http://mova.dn.ua/navchalno-metodichna-dijalnist/22--sp-911/308-----q----q--4-.html.

14. Крупка М. «Я» та «інший»: простір інтимності в романі Софії Андрухович «Сьомга». Слово $i$ час. 2008. № 8. С. 40-47.

15. Савчук Р. Методологічні засади вивчення наративного текстотворення французького художнього дискурсу XVIII - XXI століть. Науковий вісник Міжнародного гуманітарного університету. Серія: Філологія. 2016. № 20. Т. 2. С. 74-77.

16. Софія Андрухович, письменниця: Моя нова книга має смак червоної риби з лимонним соком $\mathrm{i}$ приправлена прянощами. Розмовляв Д. Шульга. 1 квітня 2007 року. URL: https://rozmova.wordpress. com/2019/03/25/sofiya-andrukhovych-5.

17. Штейнбук Ф. Тілесний міметизм (феномен монструозності) у сучасній літературі. Слово i Час. 2007. № 12 (564). С. 24-33.

\section{REFERENCES}

1. Abrantes A. (2021) From Space to Mental Space: A Cognitive Perspective into Narrative and the Architecture of the Human Mind. Diffractions, no. 3, pp. 10-28.

2. Greimas A.J. (1987) On Meaning: Selected Writings in Semiotic Theory. Ed. and trans. P. Perron and F. Collins. Minneapolis: University of Minnesota Press.

3. Language - Literature - the Arts: A Cognitive-Semiotic Interface [eds. Elzbieta Chrzanowska-Kluczewska, Olga Vorobyova] (2017) Frankfurt-am-Maine: Peter Lang, 2017.

4. O’Toole Lawrence M. (1980) Dimensions of Semiotic Space in Narrative. Poetics Today. Vol. 1, no. 4. Narratology II: The Fictional Text and the Reader, pp. 135-149. 
5. Snævarr S. (2010) Metaphors, Narratives, Emotions. Leiden, The Netherlands.

6. Andrukhovych Sofia. (2014) Siomga. Roman. [The Salmon. Novel] K.: Nora-Druk (in Ukrainian).

7. Veshchykova O. (2016) "Osoblyvi" budynky u prozi Halyny Pahutiak [The "special" houses in Halyna Pahutiak's fiction]. Suchasni literaturoznavchi studii. Fenomen domu v literaturoznavchii perspektyvi. Zbirnyk naukovykh prats, vol. 13. Hol. red. N. Vysotska. K. : Vyd. tsentr KNLU, pp. 92-103.

8. Haleta Olena. (2011) Neznaiome tilo suchasnoi ukrainskoi prozy: zhinocha literatura vid Vasylia Gabora. Paradyhma, vol. 6, pp. 234-266.

9. Hanoshenko Yu. (2017) Zamulene mezhyrichchia: mezha yak konstruent identychnosti v romani "Mesopotamia" Serhiia Zhadana [The interfluve silted up: the border as an identity constryent in the Serhii Zhadan's novel "Mesopotamia"]. Naukovi pratsi Chornomorskoho derzhavnoho universytetu imeni Petra Mohyly kompleksu "Kyievo-Mohylianska akademiia". Seriia: Filolohiia. Literaturoznavstvo, vol. 301, no. 289 , pp. $14-18$.

10. Horodniuk N. (2017) Res incognita: semiotyka rechi u skhidnoslovianskomu modernistskomu romani pershoi polovyny XX stolittia: monohrafiia [Res incognita: semiotics of the thing in the East-Slavic novel of the $1^{\text {st }}$ half of the 20st century]. Dnipro: Svidler A. (in Ukrainian).

11. Grebeniuk Tetiana. (2016) "Mahichnyi triuk, yakyi nesyla rozghadaty": arkhitekturnyi ekfrazys u romani Sofii Andrukhovych "Feliks Avstriia" ["The magic trick that is too difficult to solve": the architectural eckphrasys in the Sofia Andrukhovych's novel "Feliks Avstriia"]. Suchasni literaturoznavchi studii. Fenomen domu v literaturoznavchii perspektyvi. Zbirnyk naukovykh prats, vol. 13. K.: Vyd. tsentr KNLU, pp. $175-187$.

12. Hreimas Alhyrdas Zhiulen, Fontanyi Zhak. (2007) Semyotyka strastei. Ot sostoianyia veshchei k sostoianyiu dushy: Per. s fr. [Semiotics of passionas. From the state of things - to the state of soul]. M : Yzdatelstvo LKY (in Russian).

13. Zahnitko A. Lektsiia "Metody analizu dyskursu i tekstu: naratyvna semiotyka (strukturna semantyka)" ["Methods of discourse and text analysis: narrative semiotics"] (in Ukrainian) URL: http://mova.dn.ua/ navchalno-metodichna-dijalnist/22--sp-911/308-----q----q--4-.html

14. Krupka M. (2008) "Ia" ta "inshyi": prostir intymnosti v romani Sofii Andrukhovych "Siomha" ["I" and "the Other": the space of intimity in the novel by Sofia Andrukhovych "The Salmon"]. Slovo $i$ chas, no. 8, pp. 40-47.

15. Savchuk R. (2016) Metodolohichni zasady vyvchennia naratyvnoho tekstotvorennia frantsuzkoho khudozhnoho dyskursu XVIII-XXI stolit'. [Methodological bases of the narrative text-creating studies in the French fiction discourse of the 18-21 senturies] Naukovyi visnyk Mizhnarodnoho humanitarnoho universytetu. Seriia: Filolohiia, no. 20, vol. 2, pp. 74-77.

16. Sofiia Andrukhovych, pysmennytsia: Moia nova knyha maie smak chervonoi ryby z lymonnym sokom i prypravlena prianoshchamy. Rozmovliav D. Shulha. 1 kvitnia 2007 r. Interview. [Sofiia Andrukhovych, the writer: my new book has a taste of red fish with the lemon juice, and is spicy. Conversed D. Shulha] URL: https://rozmova.wordpress.com/2019/03/25/sofiya-andrukhovych-5.

17. Shteinbuk Feliks. (2007) Tilesnyi mimetyzm (fenomen monstruoznosti) u suchasnii literaturi [Bodily mimetics (monstrosity phenomenon) in the contemporary fiction]. Slovo $i$ Chas, no. 12 (564), pp. 24-33. 